\title{
[O'Environment and Planning
}

\section{Hybridity, possibility: Degrees of marketization in tradeable permit systems}

\begin{tabular}{|r|l|}
\hline Journal: & Environment and Planning A \\
\hline Manuscript ID & EPA-2016-0551.R3 \\
\hline Manuscript Type: & <font color="\#622108"> Theme issue Paper</font color> \\
\hline Keywords: & $\begin{array}{l}\text { Markets, Tradeable permits, Marketization, Environmental policy, } \\
\text { Financialization of nature }\end{array}$ \\
\hline \multicolumn{2}{|l}{} \\
\hline
\end{tabular}

SCHOLARONE ${ }^{1 m}$

Manuscripts 


\section{Hybridity, possibility: Degrees of marketization in tradeable permit systems}

Tradeable permit systems for allocating rights to impact the environment have become an important part of the regulatory toolkit over the last 35 years. Informed by elegant neoclassical economic thought, these regulatory markets promise lowest-cost environmental benefit by delegating decision-making to market participants. This article examines tradeable permits systems, including cap-and-trade carbon markets, tradeable water quality permits, and individual transferable quotas for fisheries, to understand the actual outcomes of attempts to transfer environmental governance to markets. Drawing on heterodox economic thought and the neoliberal natures literature, this article examines the institutional forms tradeable permit systems engender in conjunction with a neoclassical definition of 'market' to provide an internal critique of environmental marketization. In general, tradeable permit systems do not facilitate highly liquid financial markets that might signal the increasing importance of regulatory markets as an accumulation strategy for capital. Instead, market-based regulation tends to behave rather differently, acting as performance standards, quotas, or environmental taxes. The article concludes by reflecting on the political possibilities afforded by the recognition that regulatory markets, for the most part, bear little resemblance to high-flying financial markets.

Keywords: Markets, Marketization, environmental policy, tradeable permits, financialization of nature

Over the past 35 years, policymakers, their business allies, and academic economists have increasingly attempted to couple markets with environmental regulation. Proponents claim that markets are the most efficient way of distributing the costs of environmental regulation, allowing the state to define targets for degradation, and then letting markets determine where reductions in degradation are most cheaply accomplished. Market-based regulation through tradeable permit systems (TPS, or 'cap-and-trade'), nominally meant to address problems ranging from aquatic species loss to ozone depletion, have been deployed across the world. This has contributed to the alarm of many scholars about the potential for the wholesale commodification nature (e.g. Castree 2008; Büscher et. al 2012), signaling a worrying trend towards the marketization of just about everything (Sullivan 2013; Büscher and Fletcher 2015). However, such claims merit scrutiny if we are to have a robust understanding of the capital/nature nexus as it is produced through regulatory programs like TPS. Are TPS turning nature in to a set of interlinking markets such that non-human environments can only be reproduced through the circulation of capital? And does the extension of financial logics into environmental management create new and important conduits for capital? If the answer to these questions is negative, then what sorts of finance/nature entanglements are TPS creating?

The aim of this paper is to evaluate TPS on their own terms, as an avenue to policy engagement in post-political settings that might not otherwise be accessible (Swyngedouw 2014, Bigger and Robertson 2017). I argue that justifications for the use of TPS for environmental regulation that depend on the creation of liquid financial markets for trading the rights to degrade nature are rarely fulfilled in practice. Instead, efforts at their implementation represent a spectrum of modes of environmental governance. These arrangements range from more conventional regulation with added layers of bureaucracy to highly liquid financial markets, but each TPS may fit different categories at different times. This article focuses on existing TPS, particularly the California carbon market where the author conducted 14 months of ethnographic field work. This fieldwork involved observation at more than 50 regulatory hearings and industry events, supplemented with interviews with key regulators, business associations, and environmental NGOs. The 
ethnographic observations are coupled with data and secondary literature on Water Quality Trading markets, tradeable fishing rights, and both sympathetic and critical evaluations of other TPS.

The next section surveys literature on the financialization of nature and introduces a theoretical framework that incorporates political and cultural economy approaches. I use this approach to interpret the degree to which TPS create markets conforming to backers' expectations, to examine the possibility for policy hybridity that features market infrastructure, and to understand how actually-existing TPS function political-economically. I discuss the neoclassical economic basis for TPS, and the range of settings to which they have been applied. I present my interpretation of Ben-Porath's stylized (1980) definition of a market, providing a set of emic criteria against which we can interpret the operation of TPS. I use these criteria, along with heterodox economic thought on how facets of the socionatural world are 'rendered economic' to evaluate the degree to which a given TPS is 'marketized' according to neoclassical terms. The subsequent section elaborates three categories of challenges faced by TPS that restrict marketization: lack of participants, challenges with making natures fungible, and regulatory choices. If no, or limited, trading is present, then much of the effort that goes into setting up a TPS is largely for naught and alters how we might interpret these programs within broader capitalist political economy. The promise of TPS is that trading engenders least-cost emissions reductions by allowing rights to degrade nature to circulate among market participants resulting in optimal allocation of both rights and economic activities. This approach is portrayed as beneficial for individual firms who will have the flexibility to choose between reducing their environmental impacts or buying the right to degrade from others. TPS are thus meant to engender least-cost, flexible solutions at levels of firms, sectors, and throughout the economy: in short, maximizing efficiency (Tietenberg 2006; see Felli 2014).

The penultimate section will examine what more conventionally market-like TPS have in common. The majority of tradeable permit systems operate somewhere in between a complete lack of market behavior and highly liquid financial markets. However, TPS tend to engender sprawling state apparatuses to facilitate and manage the circulation of capital and the right to degrade in these programs. That circulation, where it exists at all, is often unidirectional where one of the transacting parties is the regulatory authority. The transfer of capital may not be through market exchange, but instead, circulation is accomplished through purpose-built infrastructure, effectively operating as taxes or subsidies depending on the direction of the flow. The article concludes with reflections about the challenges and opportunities that the continuing roll-out of TPS presents for regulators, the role of finance in environmental regulation, and how geographers might engage with policymakers.

\section{Performing market governance in capitalist world ecology}

Geographers have long been at the forefront of interpreting the neoliberalization of nature, of which TPS is an exemplar (Castree 2008a, 2008b, Bakker 2010). Much of this work has enhanced understanding of the vast universe of market based instruments (MBIs) for environmental policy. This literature includes work on TPS (e.g. Mansfield 2004, 2006; Cooper 2015; Carton 2016), but has also focused on forms of market governance like wetland banking (Robertson 2004, 2006), stream mitigation banking (Lave 2012), or payments/compensation for environmental services (PES/CES) (Osborne 2011, McAfee 1999, McAfee and Shaprio 2010). This literature has coincided with the rise of the 'financialization thesis', or the notion that 
finance plays an increasingly important role in the global economy (Krippner 2005, Lapavitsas 2009, French et al 2011, Moore 2011a). However, Christophers (2015a) pushed back this thesis, demonstrating shortcomings, including financialization's propensity to burst its analytical banks, losing purchase by coming to encompass many distinct practices and outcomes. As Ouma (2016, 82) notes, "[f]requently, 'financialization' has been turned into an abstract force sui generis, morphing from explanandum into explanans. In this regard, it has shared the fate of other concepts such as 'capitalism', 'the market', 'globalization' or 'neoliberalism'."

This article seeks to avoid those pitfalls by unpacking the sundry challenges that are inherent in marketizing nature through TPS. It does so by heeding the call of Berndt and Boeckler $(2010,1)$ for, "intensified efforts to understand how real (as opposed to ideal) markets are produced, stabilized and reshaped, and fall apart." There is a nascent body of literature (to which this article seeks to contribute) that questions both the importance of new natural 'asset classes' to finance, and of finance to reproducing those natures (Dempsey and Suarez 2016, Felli 2014, Loftus and Marsh 2015).

There is a vast body of literature on carbon markets from heterodox economic perspectives in social studies of finance (e.g. Callon 2007; Blok 2010, Deschaneu 2012, Lane 2012) and political economy (e.g. Lohmann 2010; Felli 2015, Smith 2006, Knox-Hayes 2013). I draw on these literatures to move toward a synthetic understanding of the practices and outcomes of making markets via TPS. A few authors have undertaken similar work for understanding related marketbased instruments (e.g. Lapeyre et. al 2015; Hrabanski 2015), yet much of this work has been conducted outside geography scholarship. Each of these authors have demonstrated the nonmarket or not-quite market outcomes of attempts to create circulating financial representations of nature in price-based environmental governance. As Pirard and Lapeyre $(2013, \mathrm{i})$ note in the context of biodiversity banking, "[payments for ecosystems services]... clearly remain a bilateral relationship with very little or no feature of market governance or commodification," while Schomers and Matzdorf $(2013,21)$, discussing nominally market-based programs for mitigating deforestation in China, show that "the payment is in fact a compensation for legal land-use restrictions and thus not an economic incentive to forest land use changes... it is rather a program to compensate for regulatory interventions." TPS have common intellectual roots, design features, and practical challenges with other MBIs, but remain distinct in part because of their ambition to create liquid financial markets that feature infinitely substitutable or 'screentradable' representations of nature. The distinction is important for evaluating the relative import of different mechanisms that seek to bring environmental degradation into formal circuits of capital, as capital attempts to reconcile its environmental contradictions while expanding its productive horizon (Moore 2015). For example, ecosystemsmarketplace.com (2014) tallies US\$12 billion in 'market-based' programs for water quality. However, only US\$41 million of that was transacted through bilateral (non-regulatory) agreements, and only US\$7 million worth of trades took place in water quality trading markets, with the remaining US\$11.95 billion going through subsidies or administrative prices set by regulatory fiat. This paucity of circulation through market trading hardly seems to signal the impending real subsumption of nature by capital.

To analyze TPS, I combine insights from political economy and the social studies of finance, denoted here as 'performativity approaches'. While long portrayed at odds with one another, Christophers (2014) demonstrates the synthetic potential in the study of markets. Attention to 
both performative and structural conditions of circulation through markets offers more nuanced understanding of what markets do across spaces and scales. This outlook is shared by an increasing number of approaches, perhaps most directly in the nascent 'operations of capital' literature set out by Mezzadra and Neilson (2015).

To correct the tendency in performativity accounts to elide structural consequences (Fine 2003), I couple this perspective with recent insights from green and feminist political economy. Moore's (2015) work on world ecology provides a helpful explanation of the impediments to financializing nature, and can be paired with performative analyses that evaluate the ways that economic theory is enrolled in attempts to overcome those impediments. Moore elaborates a history of capitalism that turns on the selective enrollment of socialnatures (Haraway 1991) into the formal circuits of capital. The main premise of interest is that capital's growth has been, and can only be, accomplished through the exploitation of nature without compensating for its full cost, economically or environmentally (see also Mies 1986). There is significant nuance in Moore's work, but the key insight for a discussion of TPS is the importance of the 'four cheaps' for the continuing expansion of capital - labor, food, energy, and resources (2015). Moore argues we are entering a new period of capitalist crisis marked by the inability of capital to 'reproduce the conditions of its own reproduction' (14). We can interpret attempts at 'internalizing externalities,' including TPS, as the protective instinct of capital to resolve this tendency through the extension of markets more deeply and broadly in search of new sources of surplus value while ameliorating environmental problems. It is effectively an attempt to extend the spatiotemporal fix that the incursion of financial practices into new settings represents into nature (Harvey 1982, Ouma 2016). The contradiction is that enough 'free gifts' (e.g. the atmosphere as a dump) must remain unaccounted for in the extraction of surplus; TPS can thus be understood as a Polanyian double movement embodied in one regulatory instrument (Polanyi 1957, Carton 2014). This perspective also attunes us to the central role of the state in attempting to reconcile capitalism's ecological contradictions as it attempts to facilitate the circulation of capital through nature as a means of safeguarding future conditions of capital accumulation.

We can use this combined performativity/political economy approach to understand the ways in which material and ideological infrastructures are built to facilitate the circulation of capital through nature, and how structural impediments to full-blown marketization come into play alongside the challenges to marketization faced in specific environmental concerns. This is to say, rendering an environmental problem 'economized' (Çalışkan and Callon 2009) signals the possibility for market-making, but the latter will not necessarily emerge from the former. It is useful to understand the interstitial spaces these mechanisms occupy and what impacts they have. Indeed, “... [the] dynamics (of marketization) necessitate the invention of new strategies of struggle, alliance, and translation adequate to the production of subjectivities capable of working across these discontinuities and heterogeneities in antagonistic and liberating ways," (Mezzadra and Neilson, 2015, 7).

\section{Trading natures}

In contrast to the much wider category of MBIs for environmental governance, this article is concerned specifically with regulatory TPS that authorize environmental impacts. The analysis may be applicable to a range of other market mechanisms, from wetlands banking to severable green product certificates (Carton 2016), but TPS are a distinct subset of market-based 
instruments (Hrabanski 2015). The label 'market-based instruments' encompasses everything from environmental taxes to weather derivatives. As Hrabanski (2015, 143-144) notes, "MBIs constitute an extremely heterogeneous group that make little sense from an economic theory perspective... MBIs as a category look more like an asylum country for all tools with a price component."

The policy mechanism of interest here are institutional arrangements wherein regulators determine an overarching limit on the kind of behavior it is seeking to regulate, from the discharge of nutrients into a watershed to the total catch in a fishery. The regulator will then distribute the right to engage in that type of behavior as permits to polluters or resource users depending on the environmental concern under management. Regulated entities will ultimately have to control permits commensurate to the amount of that behavior they have engaged in, and surrender them to the state 1 . The primary attraction of TPS is that by making tradeable representations of environmental damage, the distributed knowledge of market actors will be harnessed, and desirable outcomes can be achieved at the lowest economy-wide cost (Tienenberg 2006). Secondly, the use of TPS is meant to introduce flexibility for regulated polluters, who can choose whether to physically reduce their environmental impact or pay (in the form of purchasing permits) someone else to reduce their share of impacts (Tietenberg 2006; Butraw, Paul, and Woerman 2012). All tradeable permit programs are couched in flexibility for actors engaged in environmental degradation, supposedly creating win/win outcomes of continuing or increased economic activity in a regulated jurisdiction along with desired environmental outcomes, despite the manifold environmental, accounting, and ethical problems that are baked into 'flexible mechanism' (Lansing 2012; Bumpus and Liverman 2008; Bumpus 2011; Dalsgaard 2013; Cavanaugh and Benjaminson 2014; Lovell 2010; Pearce 2013 ).

The use of TPS has its origins in the 1970s for air pollution control in the United States and for fisheries management in New Zealand (Lane 2012), two of the heartlands of the neoliberal counterrevolution (Harvey 2007). In both settings, general antipathy toward traditional regulation was growing along with belief that markets are always the most efficient means of organizing society (Mirowski 2013). MBIs began to proliferate across jurisdictions and environmental problems throughout the 1980s and 1990s, reaching the point in the early 2000s where the approach could be said to be hegemonic across much of the world, led by initiatives such as the European Union Emissions Trading Scheme (Lane 2012). In tallying the extent of TPS (operational or otherwise), US EPA identifies 57 water quality trading markets, more than 60 carbon markets are planned or in operation (IETA 2014), individual tradeable quotas (ITQ) for fisheries are in place across in at least 40 countries through 200 programs (Bonzon 2013), and TPS have been deployed in matters as exotic as access to landfills (Barrow 2003).

Environmental management through prices is not a new idea. It can be traced back to Pigou (1920) and the taxation of environmental bads or providing subsidies for desired environmental behaviors. Pigouvian programs have been, and continue to be, a key lever in the regulatory toolbox to achieve environmental goals. The US Department of Agriculture's soil conservation program has been offering subsidies to farmers to reduce topsoil loss since the dustbowl in the 1930s.

\footnotetext{
${ }^{1}$ This part of the process demonstrates that the use-value of permits in market governance is regulatory compliance and the potential to realize trading profits rather than attachment to any specific environmental process (Smith 2006).
} 
Partially in response to the growth of Pigouvian taxes and subsidies, Coase (1960) proposed bilateral trading of the right to impose negative outcomes on society among impacted parties. Crocker (1966) and Dales (1968) built the intellectual scaffolding for TPS, reimaging Coaseian bargaining among many polluters and a role for the state beyond the enforcement of property rights and contracts. Dale's (1968) sketch of effluent trading demonstrated how distributed decision-making about prices might achieve state-defined environmental objectives, though he was careful to differentiate this suite of policies from 'conventional' markets. In a Dalesian framework, costs would be minimized because government would inevitably over or undershoot the 'correct' level of Pigouvian taxation, as it was incapable of determining demand for undegraded nature at any given moment. Instead, markets would have a "prime facie claim to efficiency," (Dales 1968, 804).

The results of attempts to create TPS based on this intellectual heritage can be judged in any number of ways, but my approach here is to evaluate markets by the criteria of economics (see Dempsey and Robertson, 2012). Ben-Porath's $(1980,4)$ definition, a common reference point for ideal-type, neoclassical markets is "faceless buyers and sellers. . . [meeting] for an instant to exchange standardized goods at equilibrium prices." That is, the key components of marketization on which the logics of TPS rests are the presence and anonymity of buyers and sellers, fully fungible commodities, and standardized contracts at a market-derived price. Brief reflection yields serious challenges to this definition. Nature is not composed of endlessly substitutable goods (Robertson 2006), willing buyers and sellers tend not to appear without state inducement and/or existing supply and demand of underlying products (USEPA 2008), and environmental regulation and market-making is nothing if not a protracted process of negotiation (Pearce 2013). There are numerous treatments of the conceptual and practical flaws in TPS in individual instances (e.g. Lohmann 2012, Mansfield 2004, Cooper 2015), but even so, some cases bear a closer resemblance to the highly liquid, screen-tradable TPS envisioned by contemporary proponents. This version of TPS itself represents a conceptual cum ideological slippage. TPS were originally drawn up to be more purely regulatory programs operating over a relatively small spatial extent with a relatively high number of participants, so trading would be facilitated by regulated entities' familiarity with one another and with the regulator (Dales 1968; Lane 2012). It is only alongside the mania for liquidity and faith in efficient markets over the neoliberal period that market proponents have come to envision TPS engendering markets that conform to Ben-Porath's market definition (Lane 2012). These examples are very much in the minority, and yet, market-based environmental governance continues to proliferate. Thus, the institutional and economic forms that result from their implementation necessitate closer examination.

In order to implement market-based environmental governance of any kind, an environmental situation must be rendered a matter of concern (Latour 2004). If an environmental issue has not been recognized as something to be dealt with, it is illegible to notions of scarcity and distribution, and thus impossible to be treated as an economic input. Failure to render an issue a matter of concern does not mean that it is not a problem, but that it has not been recognized as such by those with sufficient power (scientific, political, or economic) to begin to adjudicate access or behaviors (Callon 1998b). Structurally it represents the incapacity or unwillingness of capital (and/or the capitalist state) to recognize, in this case, an environmental situation as a threat to future accumulation. 
The first step on the continuum that environmental concerns can be managed are conventionally defined command-and-control measures like quotas (non-tradeable) or technology standards that allocate without reference to markets. We can think of this first step as 'economization', or 'the assembly and qualification of actions, devices and analytical/practical descriptions as 'economic' by social scientists and market actors" (Çalışkan and Callon 2009, 369). In the modern policy making process, beset as it is with statutory requirements for cost/benefit analysis, economization is unavoidable. However, the details and modalities may differ significantly depending on the matter of concern that is under consideration (Çalışkan and Callon 2009).

Once rendered a matter of concern and sufficiently economized to be legible to the practices of 'economists in the wild' (Callon 1998), an environmental issue can become subject to the assignment of prices. This can take place in many ways, such as equivalency in a non-capitalist economy or administrative prices as in Pigouvian taxes. Examples include TPS where prices ostensibly arise from market behaviors but are better understood as administrative prices (discussed below). While price is a condition of market exchange, it does not necessarily signal the presence or even possibility of a market, much less the highly liquid variety envisioned by TPS backers.

At this point, arrangements begin to look more like 'normal' markets. Prices may be influenced by supply and demand relationships in illiquid markets. In many settings, illiquid markets will be difficult to distinguish from bilateral (Coasean) arrangements, save the more visible role of the state acting as a broker between parties, or more likely, acting as one of the parties, collecting rents or distributing subsidies. There may be capital circulating between private sector actors, but it is just as likely that the program will revert to Coaseian bargaining or administrative prices, or behave as a command-and-control mechanism with administrative prices and environmental caps.

Finally, we reach what proponents envision as marketization proper: highly liquid financial markets that conform to Ben-Porath's definition, and subsequently, what we can think of as financialization. Here, trading occurs without reference to underlying use value, it is a pure MM' circuit; the only reference is exchange values derivative from underlying financial products. Cases like these are rare in the world of TPS, but do exist at some periods in time, such as the outset of the European Union Emissions Trading Scheme. The economic theory underlying TPS aims to create 'normal' markets, but the operation of these programs demonstrates that this is difficult to achieve, much less sustain. The next section explores the reasons that TPS tend toward command and control rules, administrative prices, or illiquid trading regimes rather than the neoclassical markets envisioned by promoters because of that wobbly use value that turns on the multiple, at times contrasting, motivations of the state to resolve socio-ecological contradictions.

\section{Troubling markets}

While there are numerous treatments of the conceptual and practical flaws in TPS in individual instances (e.g. Lohmann 2012, Mansfield 2004, Cooper 2015), I do not contest the limited potential for TPS to behave in a way that resembles the economic theory that animates them. These arrangements are very much the exception, as evidenced by the many reasons that TPS fail to engender the circulation of capital through price-clearing markets; the replicability and durability of these arrangements are dubious. I explore the conditions for full marketization in 
the next section, but first look at the reasons that trading fails to materialize in the first place, or that TPS revert to somewhat less-than fully marketized conditions after trading has taken place.

\section{Lack of trading options}

The first set of reasons why TPS may fail to circulate capital is that there are not enough parties to transact with one another. The most straight-forward example of this kind of failure is a lack of regulated entities (Atkinson and Tietenberg 1991). In this case, there is little reason to develop screen-tradeable permits when they would still result in Coasean bargaining at best. Even where the potential for trading exists, larger actors may prefer to invest in emissions reductions technology while smaller actors fear becoming subject to the market power of their larger counterparts (Suter et. al 2013). In this setting, larger regulated entities will have no possibility to trade for compliance reasons because the smaller emitters cannot reduce their emissions enough to create a surplus large enough to fulfil the needs of the larger regulated entity. Conversely, this means that smaller regulated entities could become beholden to the prices that larger sellers can set, leading all actors to treat a market as an emissions standard (Suter et. al 2013).

One reason that a TPS may have a limited number of participants is the localized nature of many environmental problems. While the indirect causes of environmental degradation are structural (e.g. O'Connor 1994, Moore 2011a), the immediate causes and effects are often proximate, requiring rigorous boundaries to achieve environmental outcomes, limiting the number of potential trading partners. This is not an issue for the largest TPS, such as air emissions and carbon markets that may have hundreds or thousands of regulatory participants, but presents a serious challenge to marketization in, for example, watershed-scale water quality trading markets. However, larger TPS (in addition to their smaller counterparts) face another spatial problem called 'leakage', or the condition where an emitter flees a regulated jurisdiction to avoid the costs associated with compliance. Leakage has the double impact of reducing demand for permits and, in altering the supply/demand balance, reducing incentives for emissions reductions among other polluters and attendant secondary trading activity (Cullenward 2014). It is, in effect, a spatial fix to move where cheap natures remain available. ${ }^{2}$

\section{Finite substitutability}

Another factor that discourages trading are limitations on how fungible the natures in question must be to be tradeable. This is true of situations where regulators attempt to create fungibility between the emissions of point and non-point sources. For example, discharges in a watershed with both wastewater treatment plants (point) and farmers (non-point) which means regulators must account for potential inaccuracies in measurement from diffuse agricultural runoff (Greenhalgh and Selman 2012). Many water quality trading programs have experimented with trading ratios, where a more easily quantified volume of discharge must be compensated for by two or three times that amount from a less easily surveilled emitter (Greenhalgh and Selman 2012). Further, equivalency may be complicated by the way liability is assigned for environmental failures. In California's carbon market, if an offset is invalidated because, for example, the forest that was planted to sequester carbon burns down, the buyer of the offset that is liable for replacing the permits that represent the now-emitted greenhouse gases (California

\footnotetext{
${ }^{2}$ This is why market proponents (e.g. the International Emissions Trading Association (2014)), consistently advocate for globally harmonized marketization, in addition to the potential for added liquidity owing to so many mandated participants, as discussed below.
} 
2015). This makes the development of screen-tradable offsets more challenging because purchasers incur costs for evaluating the quality and conditions of production of the offsets.

\section{State-markets}

The third, and most extensive, set of factors that inhibit high-level marketization arise from the regulatory nature of markets. State-induced supply and demand is critical to understanding why many programs fail to perform as envisioned. Blignaut and van der Elst (2014) note that political uncertainty and financial risk are inextricably tethered in the creation of regulatory markets. The range of policy uncertainties that can accompany any TPS are equal to the range of decisions that go into crafting the rules of the program. These can pose risks for would-be participants, including overpayment for permits that will subsequently erode in exchange values, or the cancelation of the program without compensation. This uncertainty is common, as the US Clean Air Act expressly notes that permits do not constitute a property right (Teinenberg 2006). The non-property definition has filtered out into other TPS, including California's carbon market (California 2015), damaging a permit's potential use value as representing the potential to extract profit, leaving only regulatory compliance and discouraging secondary market activity. Regulatory uncertainty is present across the full spectrum of MES and PES schemes, but is particularly pronounced in TPS since the fundamental ambit of these programs is to induce capital circulation which is inhibited by uncertainty.

In addition to being the potentially unstable product of regulatory experimentation, these market institutions feature prohibitions on behaviors that would be common in non-administrative markets. For example, in the California carbon market there are price controls, permit holding limits, restrictions on borrowing from future emissions allowances, and limitations on how proceeds from trading gains can be spent for some market participants (California 2015). These restrictions flag the variety of state motivations that are embodied in regulatory programs, seeking to address environmental issues by facilitating capital circulation - just not too much of it or in the wrong direction. Many of these prohibitions are a means of encouraging market stability by limiting price volatility or the expressions of market power - in short, risks that come with financial markets. However, these restrictions, particularly holding limits, significantly constrain trading behaviors and are off-putting to speculators.

Even if the infrastructure of a market is completely developed and participants feel confident about the robustness of the program, there must be regulatory will and capacity to administer them. This can prove challenging in smaller jurisdictions and for less high-profile environmental issues. As Newburn and Woodward $(2012,157)$ explain in the context of water quality trading, "[f]ailure to establish credible bounds on total nutrient load may also limit demand... [which] has been a significant reason why even established programs have failed to generate many trades." This is particularly true of environmental regulations implemented during tough economic times when regulatory stringency is perceived as being at odds with economic growth (Lockhart 2016), rendering the goal of pricing cheap natures secondary to that of fulfilling capital's expansionary imperative.

Even in more liquid arrangements, regulatory uncertainty impedes market behaviors by restricting demand. This case is playing out in California currently, as courts hear challenges to the overarching legality of the program (Kasler 2017). Thus, participation in state-run auctions for emissions allowances have dropped precipitously and prices, already at the regulatorydefined floor price, have stayed constant, effectively creating a state-defined carbon price that 
behaves as a fee with limited secondary market activity. So even while the potential for circulation exists, in practice the program is mostly administrative. Another example of this complication is the US State of Virginia's experience rewriting rules, brokering agreements, and making environmental compromises to its Chesapeake Bay effluent discharge program to attract a new paper mill (Pipkin 2017). This experience also demonstrates the challenges to marketization posed by the entrepreneurial state and the impetus toward growth, whereby marketized nature is subordinated to wider political economic imperatives.

An additional impediment to inducing trading behavior is the entirely state-decided supplydemand relationship. One of the most frequent causes of 'incomplete' marketization is a weak cap, like early phases of the EU emissions trading scheme, is set above the level of actuallyexisting emissions within the regulated jurisdiction (Keohane 2009). In this case, TPS are de facto licenses to pollute at business-as-usual levels, one of the ways the EU emissions trading systems has operated, even while also functioning (sometimes) as financial market (Lohmann 2009). Where the cap is set below actual emissions levels, it may act as a performance standard for polluters who prefer the certainty of reducing emissions rather than bear the risks of trading (Suter et al 2013), a situation that is emphatically not the financialization of nature.

A frequent topic of concern among program participants and their industrial organizations in the development of California cap-and-trade was the level of oversight required of them (MSCG 2009). This oversight is exerted not only by the primary regulator, but includes surveillance by at least six different regulators or contractors (California 2016). Oversight occurs at every stage of market participation, from requiring multiple attestations for anyone involved with trading at regulated companies to the reporting of every trade with regulators to ensure compliance with permit holding limits. This level of scrutiny and the transaction costs it entails is off-putting to potential speculators who would inject liquidity and, theoretically, move closer to the 'correct' price of pollution (californiacarbon.info 2014).

The regulatory supply/demand balance is further impacted by non-market regulations that interact with the need to participate in markets. Especially in conjunction with unambitious caps, the use of command and control mechanisms, pollution fees, or technology mandates all potentially stifle trading. Extensive use of non-market mechanisms betrays a lack of total faith in markets to rectify existing market failures (effectively the existence of cheap natures) on the part of regulators. Some market proponents point to these regulatory interactions as a reason that TPS are illiquid and, as per the neoliberal playbook, will claim that the only way to fix markets is through more and 'freer' markets (Mirowski 2013). However, there is significant disagreement among professional economists about regulatory interactions between overlapping policies and the need to constrain market behaviors to ensure the stability of marketization (Gayer and Horowitz 2006). Nevertheless, the urge to 'unleash' markets is one of the key rhetorical tools for the ideological project of implanting market logics into environmental regulation in the first place, which give proponents space to, "inscribe a distinction between economy and culture/society and to conceptually separate an abstract perfect Market from concrete imperfect markets. This allows market apologists to blame unwelcome external infringements (social, cultural, political etc.) for "market failure" immunizing them from criticism" (Berdnt and Boeckler 2009, 535).

This approach to market governance tends to elide the fact no market exists in a regulatory vacuum. TPS are grafted onto existing regulatory frameworks or implemented alongside other 
kinds of regulations in cases where an environmental issue is newly rendered a matter of concern. For example, in fisheries regulations the state may try to achieve multiple environmental and social goals by including temporal restrictions on fishing, by-catch restrictions, hook limits, bans on certain fishing techniques, and export and processing rules (Grafton and McIlgorm 2009). Similarly, California's cap-and-trade program is only one of around 20 climate related regulations. These regulations range from other instruments that rely on varying levels of marketization like the trading system for production of lower carbon fuels that have tradeable certificates, to administrative measures like performance standards and green energy quotas (CARB 2014). The result of these multifaceted interactions can reduce demand in the aggregate, and for individual entities, result in a system of regulations in which trading is only one route, and often the more complicated one, to compliance (Zhang et al 2015).

\section{Higher order marketization}

Despite all the attempts to 'internalize' the costs of degradation and come to grips with the impending end of cheap nature through tradeable permit systems, there are cases of liquid TPS that engender capital circulation through the creation of secondary and derivatives markets. However, these examples remain relatively small and are very tightly regulated in comparison to the wider world of financial markets. Globally, regulatory ${ }^{3}$ carbon markets were worth around US $\$ 50$ billion in 2015, or about 15\% of ExxonMobil's market capitalization - hardly the behemoth that Richard Sandor, the founder of the Chicago Climate Exchange, predicted when he said that, "[c]arbon will be the biggest commodity in the world by 2020" (in Erlich 2010).

The examples of TPS that do work more closely to their own terms can be found among tradeable quotas for large-scale fisheries management and the largest carbon and air pollution markets. What these examples have in common are the large spatial extents over which they work, the high number of regulatory-mandated participants, the relative fungibility of the underlying matter of concern, and already existing demand for the commodities to which they are tied. Both fish and carbon credits (of the non-offset variety) are highly commoditized, reducing transaction costs among market participants. Further, particularly for fish, aggressive caps spread over a large spatial extent and are tightly enforced which can induce demand for permits that is absent in many other TPS. One reason for this is because these things (fish, greenhouse gases, and urban air pollution) are related to existing product markets with definitive relations of exchange. This contrasts with a water temperature market where the object of management is a proxy environmental service for ameliorating other environmental problems, and the emitters are a blend of public and private actors. Public actors have motivations beyond profit maximization and regulatory compliance, meaning they may engage in effluent reduction more willingly than private sector entities (USEPA 2008). Additionally, public goods are a more challenging setting than private ones for engendering circulation in general (Costanza 2006; Bakker 2009).

In addition to being spatially extensive programs built on product markets with underlying dynamics of supply and demand there are other factors that improve the chances for inducing circulation in TPS. In addition to already being commodified, it helps if the object of

\footnotetext{
${ }^{3}$ In distinction to voluntary carbon markets or 'baseline-and-credit' markets like the Clean Development Mechanism of the Kyoto Protocols, which share many features of regulatory carbon markets but are distinct in that neither has a state-defined cap, among other difference.
} 
management is plentiful and (relatively) easily made fungible. For example, the US acid rain trading program encompassed a small range of pollutants of which there were many emitters putting out many tons; there was little controversy over the one-to-one nature of individual molecules (Stavins 1998). Some fish species are similarly commoditized and caught in sufficient numbers to facilitate circulation of permits to catch them, and even in carbon markets that encompass as many as six different greenhouse gases that have different properties, sufficient work has gone into 'making things the same' (MacKenzie, 2008) such that equivalences are relatively uncontroversial. Meanwhile, it would be difficult to achieve such a settlement if one wanted to build a TPS for highly biodiverse urban boreal wetlands. There would be no underlying 'products', boundaries to ensure fungibility would need to be tightly drawn, scientific controversy over the bundle of ecosystems services provided would remain contested (or 'hot' (Callon 2009)), and supply and demand would be limited even if a sufficient 'cap' were imposed. In short, the types of environmental degradation possible to confront with TPS are extremely limited and has resulted in the development of other kinds of 'market-like' regulatory programs (Laperye and Pirard 2013).

\section{Hybridity, possibility}

Given the variety of reasons that TPS may fail to engender neoclassical markets, and the specificity of criteria that seems to encourage their function, it is unsurprising that the deployment of TPS results in diverse economic and regulatory forms. In the context of biodiversity offsetting, a different form of market-based instrument, Wynn-Jones $(2013,78)$ shows that the outcome is often a "hybrid model of governance, blending market principals with existing regulatory frameworks." This is particularly true of environmental issues that are already subject to non-market regulation. Higgins et al $(2014,464)$ describe this arrangement as "a layering of instruments and approaches, whereby policymakers seek to inject more market discipline into established procedures for procuring and contracting environmental services, reshaping existing instruments to accord more closely with neoliberal notions of competition and efficiency." Higgins et al $(2014,464)$ go on to say that the process can also proceed in the other direction, requiring "the reshaping of market-based policies instruments to make them workable and acceptable within particular contexts."

For TPS, there is a third process by which hybridity occurs. In TPS, regulators build market infrastructure, but they may not engender trading behaviors amongst their participants in ways that result in ideal-type neoclassical markets. Alternatively, they may actual result in market-like arrangements for a time, only to revert to administrative prices or performance/effluent standards. For example, the California carbon market saw substantial trading activity at the outset of the program, only to become more-or-less an administrative carbon price that acts much like a carbon fee under a cap with significant regulatory interaction. This demonstrates that even where the conditions are largely favorable to the use of TPS for making markets that correspond to ideal-type economic theory, it is challenging to create durable conduits for capital circulation.

This situation, in and of itself, is not a problem, and indeed is likely desirable if key provisions are in place. The cap does the environmental work, a price on emissions ought to act as a disincentive for emitting, especially when bolstered by a regulatorily-determined price floor, and the infrastructure of TPS requires the state to develop surveillance mechanisms that may not have existed (Felli 2015; Dempsey and Robertson 2012). However, for the proponents of marketization, the creation of unidirectional transfers or the state being placed at the center of 
circulation violates one of the aims of TPS, which is to facilitate the circulation of capital between emitters and through capital markets more broadly. Instead, TPS often result in unidirectional transfers of capital to the state (tax), or a transfer from one emitter to another with the state acting as a broker (tax and subsidy), and in this way, cheap nature is accounted for to some degree, even if not to a degree that effects material changes in the economy.

The critique of TPS as a unidirectional payment in the form of a tax has continuously been leveled at the California cap-and-trade market (Carrol 2016). Regulators and legislators claim that cap-and-trade is not a revenue program for the state; however, the program has brought in more than US\$4 billion in the first three years of the program, which the state then distributes in the form of subsidies and infrastructure spending to meet its climate goals (Carrol 2016). The development of a TPS is an arduous way to implement a revenue program for the state. Stephson and Shabman $(2011,21)$ argue that, "pursuit of revenue through trading is likely to divert policy makers' time and attention from more effective means of financing... reductions," a sentiment that rings true across the world of TPS because of the associated administrative costs. However, the widespread deployment of TPS over these objections highlights the power of market discourse over environmental regulation, and so regulators find themselves going through the motions of market-making to achieve any level of environmental protection.

Enormous work goes into building infrastructure for TPS, whatever their outcome. This resonates with Graeber's $(2015,7)$ 'Iron Law of Liberalism', which states that rather than reducing bureaucracy, every attempt to create markets results in the expansion of the administrative apparatus. TPS demonstrate that creating a liquid financial market is not necessary for bureaucratic expansion - the discourse alone is sufficient. In California, the creation of the cap-and-trade market required the hiring or repurposing of two hundred environmental regulators along with countless hours of work from NGOs, regulated industry, legislative assistants, academic economists, third party data providers, financial infrastructure firms, and industry associations.

Some regulators feel as though their time would be better spent directly regulating whatever matter of environmental concern they are tasked with. In the context of controlling nutrient runoff through WQT, a USEPA report says that, "the most efficient tactic may be to simply direct funds to non-point source control, either through grants to farmers (as currently exists) or through development of a regulatory program that explicitly controls agricultural runoff," (US EPA 2008, 3-27). This is a common theme across TPS even though one of the justifications for the use of TPS is administrative simplicity. For example, in tradeable fisheries quotas, "the OECD found that management costs rose in 18 out of 23 fisheries that implemented ITQs" (Grafton and McIlgorm 2009, 715).

While this analysis has focused on the processes of deploying economic thought for the marketization of environmental problems, the raison d'être of TPS is to achieve environmental goals. Despite the time and money that have gone into developing TPS for water quality in the United States, one out of 57 existing programs improved the watershed (USEPA 2008, 3-10), while falling emissions under the European carbon trading market are mainly attributable to the financial crisis (Bailey et. al 2011). $\mathrm{SO}_{\mathrm{x}}$ and $\mathrm{NO}_{\mathrm{x}}$ trading, TPS backers' shining example, benefited greatly from changing political economic conditions, and what reductions were achieved occurred slowly compared to those accomplished by other countries that implemented regulations without trading (Lipow 2007). 


\section{Conclusion}

TPS rarely result in the highly liquid, price clearing financial markets we might envision when we think of, for example, warnings about subprime carbon (Chan 2009) or the real subsumption of nature by capital (Smith 2006). While TPS do not need to generate the circulation of capital to achieve their (generally modest) environmental goals, trading is the primary selling point of using market mechanisms because of the flexibility it affords regulated polluters and the economic efficiencies gained by allowing capital to flow to least-cost emissions reductions. Instead, these programs often behave more like command and control regulations or administrative prices, failing to meet their emic goals of market-determined prices of environmental degradation through liquid trading and circumventing inefficient state decision making. Despite the ongoing challenges facing TPS, proponents continue to advocate for these policy mechanisms as the best way to achieve environmental outcomes at the lowest economywide cost (IETA 2014). As capital, and most capitalist states, comes to recognize the magnitude of the threat to future accumulation posed by our sundry environmental crises, policy experimentation with mechanisms that promise to resolve environmental contradictions while functioning as new circuits of capital are likely to remain appealing. As such, it behooves us to not only understand how these programs fit within the economy as a whole, but also the ways TPS function in unique settings, but with key similarities.

By toggling between performativity approaches and green political economy, I have tried to demonstrate how structural impediments to building markets in environmental degradation manifest in different ways and in different kinds of nature. Regulators often must balance goals when designing programs to find solutions to capital's environmental contradictions, the biophysical properties of the concern under management may be recalcitrant to commodification, and the regulatory products of the application of neoclassical theory to those biophysical phenomena are difficult to stabilize to the extent they achieve a use value other than regulatory compliance. While different TPS fail to create liquid financial markets for different, and at times idiosyncratic reasons, the overarching lesson is that, as a mechanism, TPS are having a difficult time coming to grips with the end of cheap nature and capitalism's environmental contradictions.

However, even if TPS do not result in institutional forms that facilitate the circulation of capital through nature, or do not result in the circulation of private capital if they do achieve some level of circulation, they can potentially discipline targeted polluters to technocratic, if inefficient, management regimes, providing environmental regulators with mechanisms by which to pursue their goals within the constraints in which they find themselves (Dempsey and Robertson 2012) and create rents for the state (Felli 2014). Building on Callon (2007), Berndt and Boeckler $(2010,7)$ note that practices of making markets leads to "the possibility of co-construction of economy and politics... due to their incompleteness and dynamics markets trigger the emergence of matters of concern... spur the proliferation of new social identities and trigger the creation of unexpected social communities." Geographers could use the incompleteness of market making to insert themselves into policy processes, demonstrating ways that the mechanisms developed for TPS can be used to other ends (Bigger and Robertson 2017). To be sure, there are cases where financial practices are influencing our relationships to non-human nature in ways that look like the markets of neoclassical environmental economists, as in the growing market for green debt (Bracking 2015). Wall Street is indeed a way of organizing nature, and it is increasingly trying to account for the end of cheap natures (Moore 2011b, 2015). We must remain attuned to ways 
nature and capital are being (re)produced through financial and regulatory practices - it just may be that TPS are not the mechanism by which this occurs.

\section{Works Cited}

Atkinson S and T Tietenberg (1991) Market failure in incentive based regulation: The case of emission trading. Journal of Environmental and Economic Management 21: 17-31.

Bailey I, Gouldson A and Newell P (2011) Ecological modernisation and the governance of carbon: a critical analysis. Antipode 43(3): 682-703.

Bakker K (2005) Neoliberalizing Nature? Market Environmentalism in Water Supply in England and Wales. Annals of the Association of American Geographers 95(3): 542-565.

Bakker K (2010) The limits of 'neoliberal natures': Debating green neoliberalism. Progress in Human Geography 34(6): 715-735.

Barrow M (2003) An economic analysis of the UK landfill permits scheme. Fiscal Studies 24(3): 361-381.

Ben-Porath Y (1980) The F-Connection: Families, Friends, and Firms and the Organization of Exchange. Population and Development Review 6(1): 1-30.

Berdnt C and Boeckler M (2009) Geographies of exchange and circulation I: constructions of markets. Progress in Human Geography 33(4): 535-551.

Berdnt C and Boeckler M (2010) Geographies of markets: Materials, morals and monsters in motion. Progress in Human Geography 34(1): 1-9.

Bigger P. and Robertson M (2017) Value is simple. Valuation is complex. Capitalism, Nature, Socialism. 28(1): 68-77.

Blignaut J and Van der Elst L (2014) Restoration of natural capital: Mobilising private sector investment. Development Southern Africa 31(5): 711-720.

Blok A (2010) Topologies of Climate Change: Actor-Network Theory, Relational-Scalar Analytics, and Carbon Market Overflows. Environment and Planning D: Society and Space 28:5: 896-912.

Bonzon K, McIlwain K, Strauss K and Van Leuvan T (2013). Catch Share Design Manual, Volume 1: A Guide for Managers and Fishermen (2nd ed.). Environmental Defense Fund.

Bumpus A and Liverman D (2008) Accumulation by Decarbonization and the Governance of Climate Offsets. Economic Geography 84:2: 127-155.

Bumpus A. (2011). The matter of carbon: Understanding the materiality of $\mathrm{tCO} 2 \mathrm{e}$ in carbon offsets. Antipode 43(3): 612-638.

Büscher B and Fletcher R (2015). Accumulation by conservation. New Political Economy 20(2): 273-298. 
Büscher B, Sullivan S, Neves K, Igoe J and Brockington D (2012) Towards a synthesized critique of neoliberal biodiversity conservation. Capitalism, Nature, Socialism 23(2): 4-30.

Butraw D, Woerman M and Paul A (2012) Retail electricity price savings from compliance flexibility in GHG standards for stationary sources. Energy Policy 42: 67-77.

California (2012) California Cap on Greenhouse Gas Emissions and Market-Based Compliance Mechanisms. Subchapter 10 Climate Change, Article 5, Title 17. California Code of Regulation. Sacramento: State of California.

California Air Resources Board (2014) First Update to the Climate Change Scoping Plan. Available at:

https://www.arb.ca.gov/cc/scopingplan/2013_update/first_update_climate_change_scoping_plan. pdf (accessed 1 May 2017).

CaliforniaCarbon.info (2014) State of the California cap-and-trade Market 2013/2014. Available at: http://californiacarbon.info/2014/03/21/sotm-1314/ (accessed 24 April 2014).

Çalışkan K and Callon M (2009) Economization, part 1: shifting attention from the economy towards processes of economization. Economy and Society 38(3): 369-398.

Callon M (1998) An essay on framing and overflowing: economic externalities revisited by sociology. In: Callon M. (ed) The Laws of the Markets. Oxford: Blackwell, pp. 244-269.

Callon M (2007) What does it mean to say that economics is performative? In: MacKenzie D, Muniesa F and Siu L (eds) Do Economists Make Markets? Princeton: Princeton University Press, pp. 311-357.

Callon M (2009) Civilizing markets: Carbon trading between in vitro and in vivo experiments. Accounting, Organizations and Society 34(3): 535-548.

Carrol R (2016) California's landmark cap and trade program faces uncertain future. Reuters available at http://www.reuters.com/article/us-usa-california-carbon-idUSKCN0Z100R (accessed 28 September 2016).

Carton W (2014) Environmental protection as market pathology?: carbon trading and the dialectics of the 'double movement' Environment and Planning D: Society and Space 32(6): 1002-1018.

Carton W (2016) Money for nothin' and coal for free: 'Technology neutrality' and biomass development under the Flemish tradable green certificate scheme. Geoforum 70: 69-78.

Castree N. (2008a) Neoliberalising nature: The logics of deregulation and reregulation. Environment and Planning: A 40:131-152.

Castree N. (2008b) Neoliberalising nature: Processes, effects, and evaluations. Environment and Planning A 40: 153-173.

Cavanagh JC and Benjaminsen TA (2014) Virtual Nature, Violent Accumulation: A Critical Political Ecology of Carbon Market Failure at Mt. Elgon, Uganda. Geoforum 56: 55-65. 
Chan M (2009) Subprime carbon? Rethinking the world's largest new derivatives market. Washington D.C.: Friends of the Earth.

Christophers B (2014) From Marx to market and back again: Performing the economy. Geoforum 57: 12-20.

Christophers B (2015) The limits to financialization. Dialogues in Human Geography 5(2): 183200 .

Coase R (1960) The problem of social cost. In Classic Papers in Natural Resource Economics (pp. 87-137). London: Palgrave Macmillan UK.

Cooper M (2015). Measure for measure? Commensuration, commodification, and metrology in emissions markets and beyond. Environment and Planning A, 47(9): 1787-1804.

Costanza R (2006) Nature: Ecosystems without commodifying them. Nature 443: 749.

Crocker T (1966) The structuring of atmospheric pollution control systems. In Wolozin H (ed) The Economics of Air Pollution. New York: Norton, 1966, pp.61-86.

Cullenward D (2014) Leakage in California's carbon market. The Electricity Journal 27(9): 3648.

Dales JH (1968. Land, water, and ownership. The Canadian Journal of Economics/Revue canadienne d'Economique 1(4): 791-804.

Dalsgaard S (2013) The commensurability of carbon: Making money and value of climate change. Hau 3(1): 80-98.

Dempsey J and Robertson M (2012) Ecosystem services: Tensions, impurities, and points of engagement within neoliberalism. Progress in Human Geography 36(6): 758-779.

Dempsey J and Suarez D (2016) Arrested Development? The Promises and Paradoxes of "Selling Nature to Save It" Annals of the American Association of Geographers 106(3): 653-671.

Descheneau P (2012) The currencies of carbon: carbon money and its social meaning. Environmental Politics 21(4): 604-620.

Erlich N (2010) Carbon Could Be No. 1 Commodity: Exchange Chief. CNBC, 26 April 2010. Available at: http://www.cnbc.com/id/36782147 (accessed 1 May 2017).

Fine B (2003) Callonistics: a disentanglement. Economic Sociology 32: 478-484.

Felli R (2014) On climate rent. Historical Materialism, 22(3-4): 251-280.

Felli R (2015) Environment, not planning: the neoliberal depoliticisation of environmental policy by means of emissions trading. Environmental Politics 24(5): 641-660.

French S, Leyshon A and Wainwright T (2011). Financializing space, spacing financialization. Progress in Human Geography 35: 798-819.

Gayer T and Horowitz JK (2006) Market-based approaches to environmental regulation. Foundations and Trends ${ }^{\circledR}$ in Microeconomics 1(4): 201-326. 
Greenhalgh S and Selman M (2012) Comparing Water Quality Trading Programs: What Lessons Are There to Learn? Journal of Regional Analysis and Policy 42(2): 104.

Graeber D (2015) The Utopia of Rules: On Technology, Stupidity, and the Secret Joys of Bureaucracy. London: Melville House.

Grafton R and A McIlgorm (2009) Ex ante evaluation of the costs and benefits of individual transferable quotas: A case-study of seven Australian commonwealth fisheries Marine Policy 33(4): 714-719.

Hahn T, McDermott C, Ituarte-Lima C, Schultz M, Green T and Tuvendal M (2015). Purposes and degrees of commodification. Ecosystems Services 16: 74-82.

Harvey D (1982) The Limits to Capital. Oxford: Oxford University Press.

Harvey D (2007) A Brief History of Neoliberalism. Oxford: Oxford University Press.

Higgins V, Dibden J, Potter C, Moon K, and Cocklin C (2014) Payments for Ecosystem

Services, neoliberalisation, and the hybrid governance of land management in Australia. Journal of Rural Studies 36: 463-474.

Hrabanski M (2015) The biodiversity offsets as market-based instruments in global governance: Origins, success and controversies. Ecosystem Services 15: 143-151.

International Emissions Trading Association (2014) The World's Carbon Markets: A Case Study Guide to Emissions Trading. Available at: http://www.ieta.org/worldscarbonmarkets. (accessed November 19, 2014).

Kasler D (2017) California's carbon market in the clear? Not so fast. Sacramento Bee, 14 April 2017. Available at: http://www.sacbee.com/news/politics-government/capitolalert/article144634284.html. (accessed 1 May 2017).

Keohane N (2009) Cap and Trade, Rehabilitated: Using Tradable Permits to Control U.S. Greenhouse Gases. Review of Environmental Economics and Policy 3(1): 42-62.

Knox-Hayes J (2013) The spatial and temporal dynamics of value in financialization: Analysis of the infrastructure of climate markets. Geoforum 50: 117-128.

Krippner G (2005). The financialization of the American economy. Socio-economic review 3(2): 173-208.

Lane S (2012) The promiscuous history of market efficiency: the development of early emissions trading systems. Environmental Politics 21(4): 583-603.

Lansing D (2011) Realizing carbon's value: discourse and calculation in the production of carbon forestry offsets in Costa Rica. Antipode 43(3): 731-753.

Lapavitsas C (2009) Financialised capitalism: crisis and financial expropriation. Historical Materialism 17: 114-148.

Lapeyre R, Froger G, and Hrabanski M (2015) Biodiversity offsets as market-based instruments for ecosystem services? From discourses to practices. Ecosystem Services 15: 125-133. 
Latour B (2004) Why has critique run out of steam? From matters of fact to matters of concern. Critical Inquiry 30: 225-248.

Lave R (2012) Fields and Streams: Stream Restoration, Neoliberalism, and the Future of Environmental Science. Athens, GA: University of Georgia Press.

Lipow G (2007) Emissions trading: A mixed record with plenty of failures. Grist. Available at: http://grist.org/article/emissions-trading-a-mixed-record-with-plenty-of-failures/. (accessed 4 January, 2016).

Loftus A and March H (2015) Financialising nature? Geoforum 60: 172-175.

Lohmann L (2009) Climate as investment. Development and Change 40(6): 1063-1083.

Lohmann L (2010) Uncertainty markets and carbon markets: Variations on Polanyian themes. New Political Economy 15(2): 225-254.

Lovell H (2010) Governing the carbon offset market. Wiley Interdisciplinary Reviews: Climate Change 1(3): 353-362.

MacKenzie D (2008) Making things the same: Gases, emissions rights, and the politics of carbon markets. Accounting, Organizations, and Society 34: 440-455.

Mansfield B (2004) Neoliberalism in the oceans: "rationalization," property rights, and the commons question. Geoforum, 35(3): 313-326.

Mansfield B (2006) Assessing market-based environmental policy using a case study of North Pacific fisheries. Global Environmental Change 16(1): 29-39.

McAfee K (1999) Selling nature to save it? Biodiversity and green developmentalism. Environment and Planning D: Society and Space 17(2): 133-154.

McAfee K and Shapiro E (2010) Payments for ecosystem services in Mexico: nature, neoliberalism, social movements, and the state. Annals of the Association of American Geographers 100(3): 579-599.

Mezzadra S and Neilson B (2015) Operations of capital. South Atlantic Quarterly 114(1): 1-10.

Mies M (1986) Patriarchy and Accumulation on a World Scale: Women in the International Division of Labour. London: Zed Books.

Mirowski P (2013) Never Let a Serious Crisis go to Waste: How Neoliberalism Survived the Financial Meltdown. London: Verso.

Moore J (2011a) Transcending the metabolic rift: a theory of crises in the capitalist worldecology. The Journal of Peasant Studies 38(1): 1-46.

Moore J (2011b) Wall Street is a way of organizing nature: An interview with Jason Moore. Upping the Anti 12: 39-53.

Moore J (2015) Capitalism in the Web of Life. London: Verso. 
Newburn D and Woodward R (2012) An Ex Post Evaluation of Ohio's Great Miami Water Quality Trading Program ${ }^{1}$. JAWRA Journal of the American Water Resources Association 48: 156-169.

O’Connor M (1994) The second contradiction of capital. Capitalism, Nature, Socialism 5(4): 105-114.

Osborne T (2013) Fixing carbon, losing ground: payments for environmental services and land (in)security in Mexico. Human Geography 6(1): 119-133.

Ouma S (2016) From financialization to operations of capital: Histroricizing and disentangling the finance/farmland nexus. Geoforum 72: 82-93.

Pearse R (2013) Back to the land? Legitimation, carbon offsets and Australia's emissions trading scheme. Global Change, Peace and Security 25(1): 43-60.

Pigou A (1920) The Economics of Welfare. London: MacMillan.

Pipkin W (2017) New plant on James River to require 1st pollution trade of its kind in VA. Bay Journal, 22 January 2017. Available at:

http://www.bayjournal.com/article/new plant_on_james_river to require_1st_pollution_trade_o f_its_kind_in_va (accessed 1 May 2017).

Pirard R and Lapeyre R (2014) Classifying market-based instruments for ecosystem services: A guide to the literature jungle. Ecosystem Services 9: 106-114.

Polanyi K (1957) The Great Transformation. Boston: Beacon Books.

Robertson M (2004) The neoliberalization of ecosystem services: wetland mitigation banking and problems in environmental governance. Geoforum 35(3): 361-373.

Robertson M (2006) The nature that capital can see: science, state, and market in the commodification of ecosystem services. Environment and Planning D: society and space, 24(3): 367-387.

Schomers S and Matzdorf B (2013) Payments for ecosystem services: A review and comparison of developing and industrialized countries. Ecosystem Services 6:16-30.

Stavins R (1998) What can we learn from the grand policy experiment? Lessons from SO2 allowance trading. Journal of Economic Perspectives 12: 69-88.

Stephenson K and Shabman L (2011) Rhetoric and reality of water quality trading and the potential for market $\square$ like reform. JAWRA Journal of the American Water Resources Association 47(1): 15-28.

Sullivan S (2013) Banking nature? The spectacular financialisation of environmental conservation. Antipode, 45(1): 198-217.

Suter J, Spraggon J and Poe G (2013) Thin and lumpy: An experimental investigation of water quality trading. Water Resources and Economics 1: 36-60. 
Swyngedouw E (2014) The post-political and its discontents: spaces of depoliticization, spectres of radical politics. Edinburgh: Edinburgh University Press.

Tietenberg T (2006) Emissions Trading: Principles and Practices. Washington D.C.: Resources for the Future.

United States Environmental Protection Agency (2008). EPA Water Quality Trading Evaluation: Final Report. Washington D.C.

Wynne-Jones S (2013) Connecting payments for ecosystem services and agri-environment regulation: an analysis of the Welsh Glastir Scheme. Journal of Rural Studies 31: 77-86.

Zhang B, Zhang H, Liu B and Bi J (2013) Policy interactions and underperforming emission trading markets in China. Environmental Science and Policy 47: 7077-7084. 